Discussion Paper No. 06-014

The Importance of Equity Finance for R\&D Activity Are There Differences Between Young and OldCompanies?

Elisabeth Mueller and Volker Zimmermann

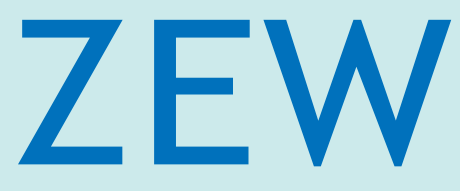

Zentrum für Europäische Wirtschaftsforschung $\mathrm{GmbH}$

Centre for European

Economic Research 
Discussion Paper No. 06-014

\title{
The Importance of Equity Finance for R\&D Activity - Are There Differences Between Young and OldCompanies?
}

\author{
Elisabeth Mueller and Volker Zimmermann
}

Download this ZEW Discussion Paper from our ftp server:

ftp://ftp.zew.de/pub/zew-docs/dp/dp06014.pdf

Die Discussion Papers dienen einer möglichst schnellen Verbreitung von neueren Forschungsarbeiten des ZEW. Die Beiträge liegen in alleiniger Verantwortung der Autoren und stellen nicht notwendigerweise die Meinung des ZEW dar.

Discussion Papers are intended to make results of ZEW research promptly available to other economists in order to encourage discussion and suggestions for revisions. The authors are solely responsible for the contents which do not necessarily represent the opinion of the ZEW. 


\section{Non-technical Summary}

The innovative activity of companies is a driving force for economic growth. New developments benefit consumers by offering a greater choice of products and services; additional markets and earning opportunities for enterprises are created. Although large companies spend a high share of the total R\&D expenditure of the private sector, small and mediumsized companies (SMEs) are also important players in the innovation process. In 2004, companies with less then 500 employees contributed to $12.5 \%$ to the R\&D expenditures of the German private sector.

In this paper we analyze whether the equity capital available to SMEs affects their R\&D activity using a representative survey of German companies. Equity is important for the R\&D activity, since bank loans are difficult to obtain for R\&D projects. Banks prefer to lend to safer projects that are easier to evaluate and provide more collateral. Young companies have specific problems with bank loans due to their higher default risk and since they still need to establish a relationship with the bank. We test the hypothesis that companies with a higher equity ratio will engage more in $R \& D$ activities, measured alternatively as the probability of pursuing $R \& D$ and as the $R \& D$ intensity (ratio of $R \& D$ expenditures to sales). The hypothesis is tested separately for young and old companies.

Using banking competition at the district level as instrument to control for reverse causality, we find that a higher equity ratio is conducive to more $R \& D$ for young but not for old companies. Whereas old companies have had time to build up equity via retained profits, young companies have to rely on the original investment of the owners. In addition, should extra financing be required while the $\mathrm{R} \& \mathrm{D}$ project is executed, older companies can rely more on bank loans whereas young companies need to provide a financial cushion for bad times themselves.

The positive influence of equity financing is only found for R\&D intensity but not for the decision whether to perform R\&D. This suggests that equity is only important for higher levels of R\&D intensity, for example for young high-tech firms. These companies therefore depend on a functioning market for external equity, if the personal funds of the original owners are not sufficient to cover the financing needs. If $R \& D$ is only a minor part in the overall activities, young companies do not have a special requirement in terms of equity to finance their R\&D. It can be that for these firms the level of overall risk is low enough for banks to be more willing to extend loans. 


\title{
The Importance of Equity Finance for R\&D Activity - Are There Differences Between Young and Old Companies?
}

\author{
Elisabeth MuelleR* AND Volker ZimmermanN**
}

February 3, 2006

\begin{abstract}
This paper analyzes the importance of equity finance for the $R \& D$ activity of small and medium-sized enterprises. We use information on almost 6000 German SMEs from a company survey. Using the intensity of banking competition at the district level as instrument to control for endogeneity, we find that a higher equity ratio is conducive to more R\&D for young but not for old companies. Equity may be a constraining factor for young companies which have to rely on the original equity investment of their owners since they have not yet accumulated retained earnings and can relay less on outside financing. The positive influence is found for $R \& D$ intensity but not for the decision whether to perform R\&D. Equity financing is therefore especially important for the most innovative, young companies.
\end{abstract}

JEL classification: G 32, O 32

Keywords: R\&D activity, equity finance, small and medium-sized enterprises

${ }^{*}$ Centre for European Economic Research (ZEW), Department of Industrial Economics and International Management, L7,1, 68161 Mannheim, Germany, e-mail: Mueller@zew.de

**KfW Bankengruppe, Palmengartenstraße 5-9, 60325 Frankfurt/Main, Germany, e-mail: Volker.Zimmermann@kfw.de

Acknowledgements: This paper was written as part of a cooperation between ZEW Mannheim and KfW Bankengruppe, Frankfurt. We would like to thank David Audretsch, Ulf von Kalkreuth, Tobias Klein, Georg Licht, Thomas Hempell, Christian Rammer and Konrad Stahl for helpful discussions and Frank Reize (KfW) for making the data available. Financial support from the German Science Foundation (DFG) under the grant SFB/TR 15-04 is gratefully acknowledged. 


\section{Introduction}

The innovative activity of companies is a driving force for economic growth. Consumers benefit from a greater choice of products and services, whereas companies benefit from the creation of additional markets and earning opportunities. At the macroeconomic level, innovations speed up structural adjustment to engender new viable sectors and play a vital part for the creation of new jobs (Peters (2004)). Although large companies spend a high share of the total R\&D expenditure of the private sector, small and medium-sized companies (SMEs) are also important players in the innovation process. In 2004, companies with less than 500 employees contributed to $12.5 \%$ to the R\&D expenditures of the German private sector (Stifterverband (2005)). On the one hand, small companies face disadvantages because they cannot exploit scale economies and are restricted in the types of financing they can raise for their R\&D activities. On the other hand, some characteristics of SMEs even facilitate the implementation of R\&D projects (Acs and Audretsch (1990)). Managers may know more about the technology, there may be an entrepreneurial spirit more favourable to risk taking, and researchers may encounter fewer bureaucratic hurdles (Scherer (1991); Link and Bozeman (1991)).

The literature on $R \& D$ activity has originally mainly concentrated on the influence of company size, technological opportunity and appropriability (Cohen and Levin (1989)). More recently, the influence of the financial structure of the company has also been of interest. Whereas some authors considered the influence of cash-flows (see, for example, Himmelberg and Petersen (1994)), we focus on the influence of equity financing.

The purpose of this paper is to provide an analysis of whether the equity capital available to companies affects their R\&D activity using a representative survey of German companies from KfW Bankengruppe (formerly Kreditanstalt für Wiederaufbau). We test the hypothesis that companies with a higher equity ratio will engage more in $R \& D$ activities, measured alternatively as the probability of pursuing $R \& D$ and as the $R \& D$ intensity (ratio of $R \& D$ expenditures to sales).

We focus on unlisted, small and medium-sized companies. In contrast to listed companies, they depend for their equity financing strong on the personal funds of a limited number of owners. Furthermore, we differentiate between young and old companies. The R\&D activity of young companies is more likely to be constrained by the availability of equity capital, 
since young companies have not yet had the opportunity to increase their equity base by accumulated earnings.

Young, innovative companies have only a limited choice between different types of financing. Bank loans are not a suitable form of finance for $\mathrm{R} \& \mathrm{D}$ projects due to the high risk inherent in such endeavours (Himmelberg and Petersen (1994)). Venture capital financing is a more appropriate form. However, the VC market in Germany is not well developed (Zimmermann and Karle (2005)). In the year 2004 only 844 companies received venture capital financing (BVK (2005)), whereas there are approximately 36,000 SMEs performing continuous R\&D in Germany (Rammer et al. (2006)). 11 Furthermore the early stage segment in the German VC market is declining since the boom period at the end of the nineties. The share of the early stage segment in total fundraising decreased from 35 percent in 2000 to 3.5 percent in 2003. This shows that even investors in the $\mathrm{VC}$ market hesitate to take the high risks of young innovative firms.

In our analysis, causality can go in both directions. On the one hand, the availability of equity can influence the R\&D activity, since owners will only start R\&D projects if their capital base is sufficient to sustain projects until returns materialize. R\&D projects have often no early cash flow to pay interest on loans. Owners may be unwilling to engage in $R \& D$ if it endangers the survival of the company. On the other hand, companies with R\&D activity may find debt financing especially expensive or may not have access to this type of financing at all. In addition, if innovative companies benefit from successful R\&D projects via higher profits, they can increase their equity base through retained earnings. In order to identify the first direction of causality, we use alternatively two instruments for the equity ratio. The first instrument is competition in the banking sector at the district level; the second is a rating of the financial standing of the company, a part of the company's credit rating.

We find a significant influence of the equity ratio for the $R \& D$ activity of young but not of old companies. Young companies may therefore be constrained in their innovative endeavours by their limited access to equity financing. When differentiating between the

1 The number of R\&D performing SMEs in Rammer et al. (2006) includes only companies with at least five employees and excludes the retail sector. The statistics of the German Private Equity and Venture Capital Association (BVK) are the most comprehensive information available. According to the BVK they cover $90 \%$ of the volume of the German VC market (Krahnen and Schmidt (2004)). 
probability of $R \& D$ and the $R \& D$ intensity, only the $R \& D$ intensity is influenced by the equity ratio. For low levels of $R \& D$, the financial structure is therefore not of importance.

This paper is organized as follows. Section 2 explains theoretical considerations of financing problems. Section 3 summarizes the existing literature. Section 4 describes the data set. Section 5 describes the financing of German SMEs. Section 6 presents the empirical results. Section 7 concludes.

\section{Theoretical Background to Financing Problems}

\subsection{Problems of Debt Financing of R\&D Projects}

R\&D projects have special characteristics that make debt financing difficult.$^{2}$ First, returns of $R \& D$ projects are highly uncertain. Often there is a high probability of failure combined with the possibility of high returns if successful. Due to fixed interest payments banks do not participate in the high returns of successful outcomes, they are therefore more concerned with the probability of failure when calculating the price for the loan which can lead to high interest rates or to the decision not to lend at all (Stiglitz (1985)).

Second, the quality of $R \& D$ projects is difficult to evaluate. Not only is technical knowledge necessary, owners also want to keep details of their R\&D activity secret. The result is severe problems of asymmetric information in the form of adverse selection and moral hazard, which can lead to credit rationing (Stiglitz and Weiss (1981)). Hence, the bank may decide not to extend loans for R\&D projects.

Third, R\&D projects often do not involve assets that can be used as collateral. Wages of scientists and engineers account for a high share of $R \& D$ expenditures and if tangible assets are bought, they have often a low resale value because they are company specific. $\mathrm{R} \& \mathrm{D}$ activity therefore provides little inside collateral that could be offered to banks to make lending less risky. Bester (1985) shows that collateral can be used as a screening device to avoid rationing in credit markets. ${ }^{3}$ Furthermore, Williamson (1988) concludes from a

\footnotetext{
${ }^{2}$ Himmelberg and Petersen (1994) gives a detailed discussion of financing R\&D activities with bank loans.

${ }^{3}$ Collateral is an important instrument used by banks. In their sample of bank loans extended by five large German banks, Elsas and Krahnen (2002) find that $71 \%$ of the loans are collateralized and $31.5 \%$ of the total credit volume is covered by collateral. Lehmann et al. (2004) report average collateral coverage of $61 \%$ for Western Germany and 53\% for Eastern Germany.
} 
transaction cost economics point of view that non-redeployable assets, such as investments in $R \& D$, should be financed with equity.

\subsection{Problems of Debt Financing of Young Companies}

In addition to the problems of debt financing of $R \& D$ projects, young companies have agespecific problems with access to bank loans. Banks use relationship lending to alleviate problems of asymmetric information when lending to small companies (see, for example, Petersen and Rajan (1994) and Berger and Udell (1995)). Banks collect information about the companies over time, which allows them to make well based loan decisions. Since young companies start without such a track record, banks may be reluctant to offer loans. It often needs time for the management to establish a functioning relationship with the decision makers of their local bank branch.

A further impediment for bank loans is the higher default risk of young companies. Fritsch et al. (2004) document the probabilities for going out of business for German companies, finding a decrease in the probability of exit with firm age. After ten years only 46 percent of the start-ups in manufacturing are still in business and about 37 percent of the start-ups in services. There are several possible reasons for the higher exit rates of young companies, among them inexperienced management, problems of developing a customer base and problems of establishing the product in the market.

Schäfer et al. (2004) investigate the choice between debt and equity for young innovative SMEs in Germany. They find that banks confine the risk by concentrating on firms with a high equity ratio, high prize cost margin and smaller deal sizes if they engage in this higher risk lending activity.

\section{Related Literature}

The analysis of this paper focuses on the influence of the financial structure on the R\&D activity of companies. This direction of causality has so far found scant attention in the literature and focuses primarily on listed companies. Singh and Faircloth (2005) document for their sample of large, listed US companies a negative influence of leverage on R\&D intensity. The authors restrict their sample to companies with minimum positive R\&D expenditure and do not use instruments to establish the direction of causality. Since the 
sample excludes companies without and without continuous $R \& D$ activity, the analysis can not cover the decision to undertake R\&D. Bhagat and Welch (1995) compare the influence of leverage on R\&D intensity across countries for listed companies using a VAR approach. For the US they find a positive effect, whereas it is negative for Japan. The authors conclude that US lenders may be less willing to finance R\&D projects. Also using a VAR approach, Chiao (2002) finds a negative influence of debt on R\&D intensity for listed US companies in sciencebased industries and a positive influence for companies in nonscience-based industries.

So far, the literature is mainly concerned with the direction of causality from R\&D activity to the capital structure (see Hall (2002) for a literature survey). Aghion et al. (2004) find higher leverage for listed UK companies with R\&D activity together with an decrease in leverage in the R\&D intensity. Hyytinen and Pajarinen (2005) study the determinants of leverage for a sample of small, unlisted Finnish companies. The authors document especially low leverage for companies in the ICT sector with high R\&D intensity. Neither of the analyses uses instruments to determine the direction of causality.

A less closely related branch of the literature studies the influence of financial constraints on the investment behaviour of companies. Companies are said to be financially constrained if they face higher costs of external as compared to internal finance. Fazzari et al. (1988) look at investment in general. Harhoff (1998), Bond et al. (1999), Himmelberg and Petersen (1994) and Czarnitzki (2005) consider R\&D expenditures as a specific form of investment in future growth options.

\section{Data}

The analysis is based on a panel survey of German small and medium-sized companies conducted by KfW Bankengruppe, Frankfurt/Main, Germany (KfW-Mittelstandspanel). In addition to basic company characteristics, this data set includes information on the innovative activities of companies and their financial structure. Small and medium-sized companies are defined as companies with less than Euro 500 million turnover. There is no minimum number of employees required for the inclusion into the panel. This is a big advantage compared to other data sets, since many surveys impose a size requirement of at least five employees. We find that even the smallest companies report substantive innovative activity; for example, $10 \%$ of companies without employees have positive R\&D expenditures. It can 
Table 1: Descriptive Statistics

\begin{tabular}{|l|c|c|c|c|c|}
\hline Variable & Mean & Median & Stdev. & Min & Max \\
\hline \hline Number of employees & 47.7 & 18.5 & 82.0 & 0 & 948 \\
Company age (in years) & 31.7 & 13 & 37.5 & 1 & 410 \\
Equity ratio & 0.21 & 0.15 & 0.21 & 0 & 1 \\
R\&D intensity & 1.96 & 0 & 5.58 & 0 & 70 \\
Dummy for R\&D activity & 0.26 & 0 & 0.44 & 0 & 1 \\
\hline
\end{tabular}

Source: KfW-Mittelstandspanel, wave of 2003. All values refer to the year 2002.

also be expected that very small companies have more severe financing problems. In order to better understand the relationship between financial structure and R\&D activity for SMEs, it is important to observe the very small companies in the data. The survey covers both the manufacturing and the service sector.

The sample of the survey was determined with a stratified random sample procedure. The stratification was done according to six size groups (up to 4 employees, 5-9, 10-19, 20-49, 50-99 and 100 or more employees), five industries (manufacturing, construction, retail, wholesale and services), region (Western versus Eastern Germany) and participation in a government support programme for SMEs conducted by KfW Bankengruppe.4 We use unweighted regression procedures with controls for the stratification variables.

Information on 5,795 companies from the first wave collected in 2003 is used for the main part of the analysis. $31 \%$ of the companies are in the manufacturing sector, $18 \%$ in construction, $28 \%$ in retail/wholesale and $23 \%$ in services. Companies in the banking and insurance industry are excluded from our analysis. The section on access to bank finance draws on a combination with the second wave of 2004. Unfortunately, a panel analysis is not possible, since the second wave did not ask about R\&D activities.

Descriptive statistics for the variables are provided in Table 1. The average number of employees measured in full-time equivalents is below 50, since only small and medium-sized companies are covered. The age of the companies has a wide dispersion with an average of 32 years. The equity ratio, defined as book value of equity capital divided by total assets,

\footnotetext{
${ }^{4}$ The programmes mainly support the investment activities of existing and newly founded companies. They are based on either support for bank loans or equity capital.
} 
Table 2: Company Characteristics According to R\&D Activity

\begin{tabular}{|l|c|c|c|c|c|}
\hline & \multicolumn{3}{|c|}{ Mean } & \multicolumn{2}{c|}{ Median } \\
\hline Variable & & & Sig. lev. & & \\
\hline \hline Number of employees & R\&D & no R\&D & difference & R\&D & no R\&D \\
Total assets (in '000 EUR) & 71.0 & 39.7 & $<1 \% * * *$ & 35.5 & 15 \\
Total equity (in '000 EUR) & 8,045 & 5,985 & $<1 \% * * *$ & 3,100 & 1,450 \\
Company age (in years) & 2,085 & 1,221 & $<1 \% * * *$ & 423 & 168 \\
Equity ratio & 32.2 & 31.5 & $73 \%$ & 13 & 13 \\
Equity per owner (in '000 EUR) & 1,026 & 536 & $<1 \% * * *$ & 235 & 100 \\
No of owners & 1.96 & 1.69 & $<1 \% * * *$ & 2 & 1 \\
\hline
\end{tabular}

Source: KfW-Mittelstandspanel, wave of 2003. All values refer to the year 2002.

has an average value of $21 \% 5^{5}$ The R\&D intensity, defined as R\&D expenditures divided by sales, has a mean of $2.0 \%$ and $26 \%$ of the companies report $R \& D$ activity, i.e. positive $R \& D$ expenditures.

\section{The Financing Situation of German SMEs}

\subsection{Comparing Companies with and without R\&D Activity}

In order to get a better understanding of the financing conditions of small and medium-sized companies, we investigate whether there are structural differences between companies with and without R\&D activity. Table 2 shows descriptive statistics for both company types. A striking difference is the significantly larger size of R\&D performing companies, which is reflected in almost twice the number of employees. The larger size is also indicated by a higher value of total assets and of total equity ${ }^{6}$ There are no significant differences with

\footnotetext{
${ }^{5} \mathrm{~A}$ small number of companies with negative equity were excluded from the sample. Liabilities can exceed the assets of a company, if repeated losses eat up the equity capital. The company is not closed, if creditors believe that loans can be repaid with future profits. Companies with zero equity were retained.

${ }^{6}$ The size difference cannot be explained with companies being larger in industries that typically perform more $R \& D$ as the difference still exists after controlling for industry effects.
} 
respect to company age - the difference in the mean is negligible.

The financing choices of both company types vary markedly, illustrating a higher need for equity capital for innovative companies. The equity ratio is three percentage points higher for companies with positive R\&D activity. A difference that is statistically significant at the $1 \%$ level. In addition, owners of companies with R\&D activity on average invest a substantially higher amount. Equity per owner has a mean of Euro 1,026,000 for companies with and of Euro 536,000 for companies without R\&D activity. In order to raise enough equity, companies can tap the personal funds of several owners. This possibility is reflected in a higher number of owners in innovative companies. Both the differences in equity per owner and in the number of owners are significant at the $1 \%$ level.

The differences in the equity ratio between companies with and without R\&D can also be seen in Figure 1. The equity ratio of $R \& D$ performing firms is higher in all age groups than the equity ratio of non $R \& D$ performing firms. Over time the equity ratio increases for both groups, because companies use profits to pay back bank loans and to increase the equity capital through retained earnings.

Figure 1: The Relationship Between Equity Ratio and Age

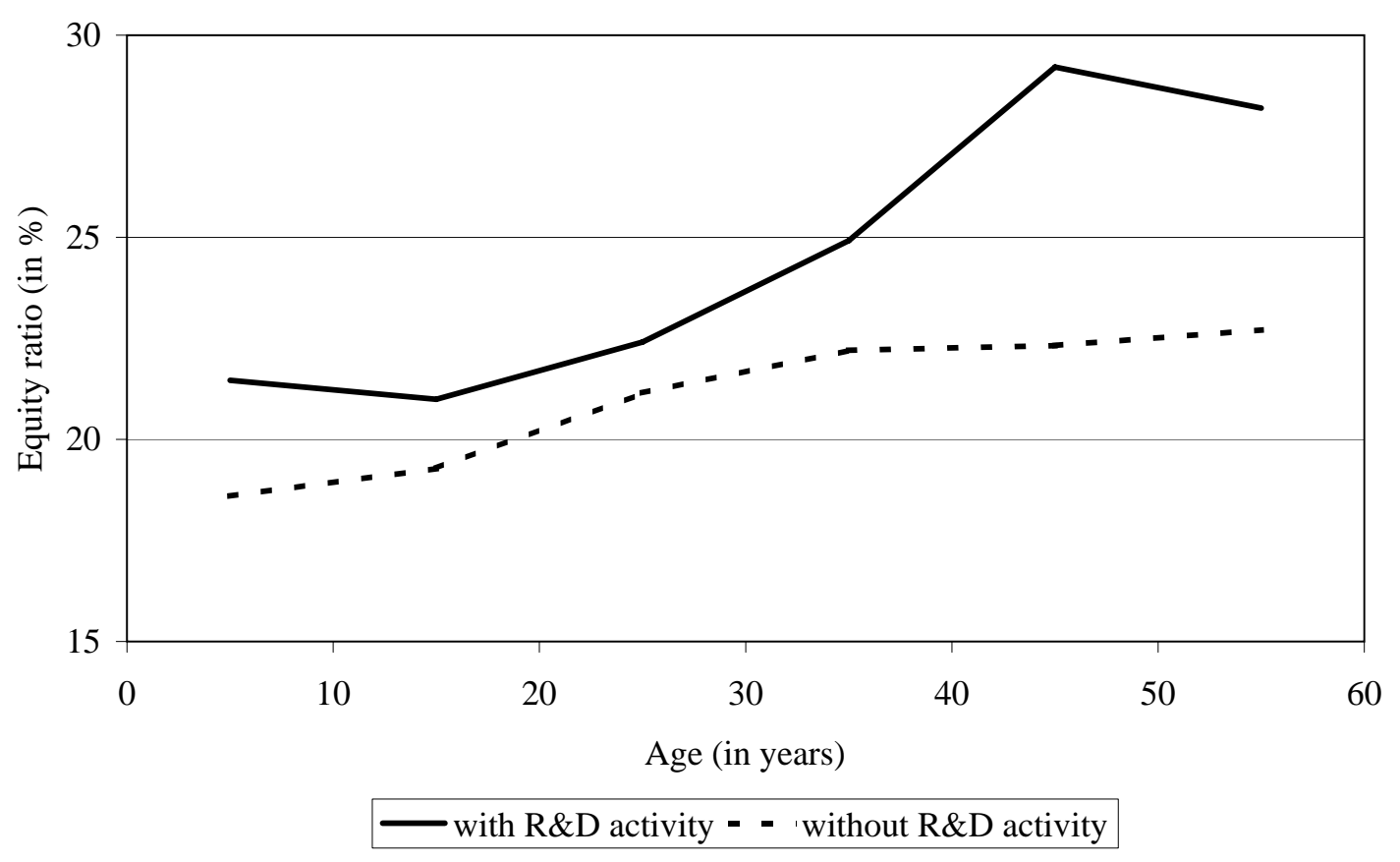




\subsection{Access to Bank Financing}

This subsection conveys an impression about which types of companies face particular difficulties in obtaining external finance. We use information on the outcome of loan applications that was asked in the second wave of the survey from companies with positive investment activity in the year prior to the survey and combine it with the R\&D information of the first wave. The number of observations is substantially lower than in the following main section, because not all companies invested in 2003 and not all companies participated in both waves.

Column (1) of table 3 shows results of a probit regression with the dependent variable equal to one if the company applied for a loan in the year prior to the survey. R\&D activity, size and age have no influence on this decision. The only significant explanatory variable is the equity ratio, with an increase in the equity ratio by one standard deviation (0.20) leading to a decrease in the probability of a loan application by 2.4 percentage points. There is no indication that companies with a higher $R \& D$ intensity have a lower demand for bank loans. However, it is possible that some companies expect a loan denial and are discouraged from applying.

The probit regression in column (2) only considers companies with loan applications and identifies the characteristics that lead to a higher probability of failed negotiations. Negotiations can either fail because the bank makes no loan offer or because the offer is rejected by the company. Of the companies which applied, $46 \%$ were unsuccessful. An important determinant for a failed negotiation is the R\&D intensity. A one standard deviation increase (0.05) leads to an increase in the probability of failure by 2.8 percentage points. This can be seen as evidence that companies with higher R\&D intensity find it more difficult to obtain a bank loan. Interestingly, if a dummy for R\&D activity is used instead, no influence on loan availability is found. Only if the R\&D activity is substantial enough to have an influence on company characteristics will there be difficulties with bank finance 7 The other significant regressor is the equity ratio with a positive influence on successful negotiations, which is plausible since companies with a high equity ratio are less likely to default.

Finally, in column (3) we investigate in more detail why negotiations failed, restricting the

\footnotetext{
${ }^{7}$ There is also an alternative explanation: companies with higher R\&D intensity may have more market power which could allow them to let negotiations fail more often.
} 
Table 3: Access to Bank Financing - Marginal Effects of Probit Regressions

Dep. variable Loan application Negotiations failed No loan offer

\begin{tabular}{lccc}
\hline R\&D intensity & 0.095 & $0.531^{*}$ & 0.199 \\
Equity ratio & $(0.205)$ & $(0.285)$ & $(0.392)$ \\
& $-0.122^{* *}$ & $-0.302^{* * *}$ & -0.170 \\
No of employees & $(0.051)$ & $(0.078)$ & $(0.112)$ \\
& 0.362 & -0.030 & $-2.171^{* * *}$ \\
Square no of employees & $(0.246)$ & $(0.326)$ & $(0.682)$ \\
& -0.001 & 0.001 & $0.003^{*}$ \\
Age & $(0.000)$ & $(0.000)$ & $(0.000)$ \\
& -0.000 & -0.001 & $-0.004^{* *}$ \\
Square age & $(0.000)$ & $(0.001)$ & $(0.002)$ \\
& 0.000 & 0.000 & $-0.000^{* *}$ \\
\hline \hline No of observations & $(0.000)$ & $(0.000)$ & $(0.000)$ \\
\hline Log likelihood & 2,107 & 1,406 & 650 \\
\hline \hline Mean of dependent variable & $-1,239$ & -928 & -399 \\
\hline
\end{tabular}

Note: $*, * *, * * *$ indicate statistical significance at the 10,5 , and 1 percent levels, respectively. Robust standard errors are in parentheses. All regressions contain industry dummies comparable to the 3-digit SIC level, a dummy for limited liability, for participating in a government support programme and for Eastern German companies. The R\&D intensity is expressed as ratio.

sample to companies with unsuccessful negotiations. The dependent variable is coded with one if the bank made no loan offer and with zero if the company received an offer but declined it. Both reasons have a similar probability of about 50\%. When evaluated at their means, both size and age have a negative effect on the dependent variable, i.e. smaller and younger companies have a higher probability of not receiving an offer by the bank. By implication, they have a lower probability of declining themselves an offer. One can claim that no matter whether no offer was received or the offer was so unfavourable that the company declined it, the economic outcome is the same: the company was unsuccessful in its effort to obtain a loan. However, we would argue that not receiving an offer at all is a sign of a weaker 
bargaining position of the company vis-a-vis the bank. With this interpretation, small and young companies are less well placed to negotiate bank loans.

\section{The Importance of Equity Finance for R\&D Activity}

\subsection{Empirical Model}

For the empirical analysis we first employ a Tobit model with the R\&D intensity as dependent variable. It takes account of the fact that many companies report zero values of $\mathrm{R} \& \mathrm{D}$ expenditure. In the Tobit model regressors have the same influence on the probability of doing a positive amount of $R \& D$ as on the $R \& D$ intensity itself, a restriction that is lifted in the second model. The hurdle model (see Cragg (1971)) consists of two parts: the first is a probit model with a dummy variable for positive amounts of $R \& D$ as dependent variable; the second is a Tobit model restricted to companies with positive R\&D. The separation into two parts allows for more flexibility. If there are differences either in the size of the influence of explanatory variables or in their significance, the hurdle model makes them transparent 8

\subsection{Controlling for Reverse Causality}

Our estimates can be influenced by reverse causality. Not only can equity capital be a prerequisite for $R \& D$ activity, it is also possible that companies with $R \& D$ activity select a capital structure with a higher proportion of equity, since bank loans can be more expensive for riskier companies. Also, companies with R\&D activity can have difficulties with obtaining a bank loan at all.

In order to identify the effect of the equity ratio on the R\&D activity, we use instruments. The first instrument is the local banking competition. Theoretically, more intense competition in the banking sector can have two effects. It can improve the availability of bank loans if banks spend more resources to identify good companies in order to keep their market share. It can also decrease the availability of loans, since companies can more easily switch from

\footnotetext{
${ }^{8}$ The Heckman selection model is not appropriate here. For companies without R\&D activity the R\&D intensity is known to be zero and therefore not missing. Furthermore, the R\&D intensity can only have nonnegative values, whereas the main equation of the Heckman model disregards this restriction (Wooldridge $(2002))$.
} 
one bank to the other. Banks therefore find it harder to obtain rents from ongoing customer relationships with good companies and may therefore be less willing to extend loans to new companies 9 The availability of loans influences the equity ratio of the companies. If loans are more easily available, companies will operate with a lower equity ratio.

We define banking competition at the district level as the number of banks active in a district divided by the population of the district. Data on the number of banks and their branches at the district level are obtained from the Bundesbank, the former German central bank. Since districts are of varying size and more banks will be active in larger districts, we use the population to normalize the variable. 10 The number of banks active in a district corresponds to the number of banks that have at least one branch in this district. For example, Deutsche Bank is not only active in Frankfurt/Main, but in each district where it operates a branch.

Whereas it is difficult to imagine that banking competition should have a direct influence on the R\&D activity of companies, there is possibly an indirect influence. Banking competition may be higher in districts with a higher income per capita, because the market is more lucrative. A higher income can be an indicator for a well educated population, which can be related to a higher average $R \& D$ intensity of the companies in the district, since R\&D intensive companies find it more attractive to settle in districts where they can find a well educated work force. In the second-stage instrumental variable regressions we therefore control for the income per capita at the district level and include dummies for a classification of districts into nine categories according to urban or rural type 11

We calculate a second set of estimates with the instrument financial standing of the companies to test the robustness of our results. The information is obtained from Germany's largest credit rating agency, Creditreform, and then merged to the KfW-Mittelstandspanel. The financial standing is an element of the overall credit rating. It is coded from one for

\footnotetext{
${ }^{9}$ Petersen and Rajan (1995) develop this argument and provide empirical evidence for this effect for US banks. However, for the German capital market with a strong relationship between the company and a single bank ("Hausbankprinzip") it can be assumed that this argument is less relevant.

${ }^{10}$ Germany is divided into 439 districts (Kreis or kreisfreie Stadt). Berlin is the largest district with a population of 3.4 million and Zweibrücken is the smallest district with a population of 36,000.

${ }^{11}$ Income per capita and population figures are taken from Statistik regional 2004, German National Statistical Offices (Statistische Ämter des Bundes und der Länder). The categorization of districts follows INKAR 2004, Federal Office for Construction and Regional Planning (Bundesamt für Bauwesen und Raumordnung).
} 
Dep. variable

Equity ratio

\begin{tabular}{lcccc}
\hline Local banking competition & $-0.014^{* *}$ & $(0.007)$ & & \\
Financial standing & & & $-0.0027^{* * *}$ & $(0.001)$ \\
No of employees & -0.027 & $(0.063)$ & -0.073 & $(0.073)$ \\
Square no of employees & 0.000 & $(0.000)$ & $0.000^{*}$ & $(0.000)$ \\
Age & $0.001^{* * *}$ & $(0.000)$ & $0.001^{* * *}$ & $(0.000)$ \\
Square age & $-0.000^{* * *}$ & $(0.000)$ & $-0.000^{* * *}$ & $(0.000)$ \\
\hline \hline No of observations & \multicolumn{2}{c}{5,795} & & 4,288 \\
R squared & \multicolumn{2}{c}{0.043} & & 0.050 \\
\hline
\end{tabular}

Note: All regressions contain a dummy for whether the company participated in a government support programme, a regional dummy and industry dummies comparable to the 3-digit SIC level. The regression in columns (1) also contains controls for income per capita at the district level and dummies for district type. Robust standard errors are in parentheses. $*$, **, *** indicate statistical significance at the 10,5 , and 1 percent levels, respectively.

the best standing to six for the worst. Suppliers of trade credit can enquire at Creditreform about the financial standing of their customers to help them with their credit decision. Since banks prefer to lend to good risks, the rating also gives an indication of how easy a company will find it to obtain bank loans. This instrument should therefore be correlated with the endogenous variable equity ratio. On the other hand, no information about R\&D activity is used to determine the financial standing. The instrument should therefore not be correlated with the dependent variable.

The results of the first-stage regressions are reported in Table 4. Column (1) reports the results for the use of banking competition. A higher degree of competition leads to a significantly lower equity ratio, i.e. the supply of bank loans improves with competition. Column (2) shows that companies with a better financial standing have a higher equity ratio. The instrument is significant to the $1 \%$ level.

\subsection{Estimates without Instruments}

In Table 5 column (1) we present the results of the Tobit model and in columns (2) to (3) the results of the hurdle model. We find a positive relationship between equity ratio and 
R\&D activity for the Tobit model and for the first part of the hurdle model covering the probability of $R \& D$. For the $R \& D$ intensity restricted to $R \& D$ performing companies we find a positive but insignificant effect. These results can be influenced by reverse causality since the equity ratio is not instrumented.

Evaluated at the mean of the number of employees we find a positive influence of size on R\&D for the models of columns (1) and (2) and a negative influence for column (3). Large companies have therefore a higher probability of pursuing R\&D but with a lower intensity. The age variable has a negative effect at its mean in all three models. The control for limited liability shows a positive influence on the probability of $R \& D$, but no influence on the $R \& D$ intensity of R\&D performing companies. We also control for participation in a government support programme, a regional indicator and industry classification, because these variables were used to stratify the random sample.

Columns (4) to (6) contain the same econometric models with an interaction term allowing for a different influence of the equity ratio at young and old companies ${ }^{12}$ A company is defined as young if it is ten years or younger. For old companies we do not find an influence of the equity ratio any more. However, the equity ratio has a significant effect for the R\&D intensity of young companies, both when all companies and when only the R\&D active companies are considered. Since we use no instruments here, it is not clear whether this effect should be interpreted as indicating equity as necessary financing type for $R \& D$ or as R\&D intensity influencing the financial structure of the young companies. There is no influence of the equity ratio on the probability of performing R\&D.

\subsection{Estimates with Instruments}

In order to identify the direction of causality, we instrument the variable equity ratio. Table 6 presents results with local banking competition used as instrument. The specifications in columns (1) to (3) without interaction terms show now no significant influence of the equity ratio. This can be either a sign that the instrument is too weak or that the previous regressions where influenced by reverse causality.

For the specifications with interaction term we confirm the pattern found without instruments. The equity ratio has a significant influence on the R\&D intensity of young companies

\footnotetext{
${ }^{12}$ The sample contains 1,873 companies up to the age of 10 years ( $32 \%$ of the total).
} 


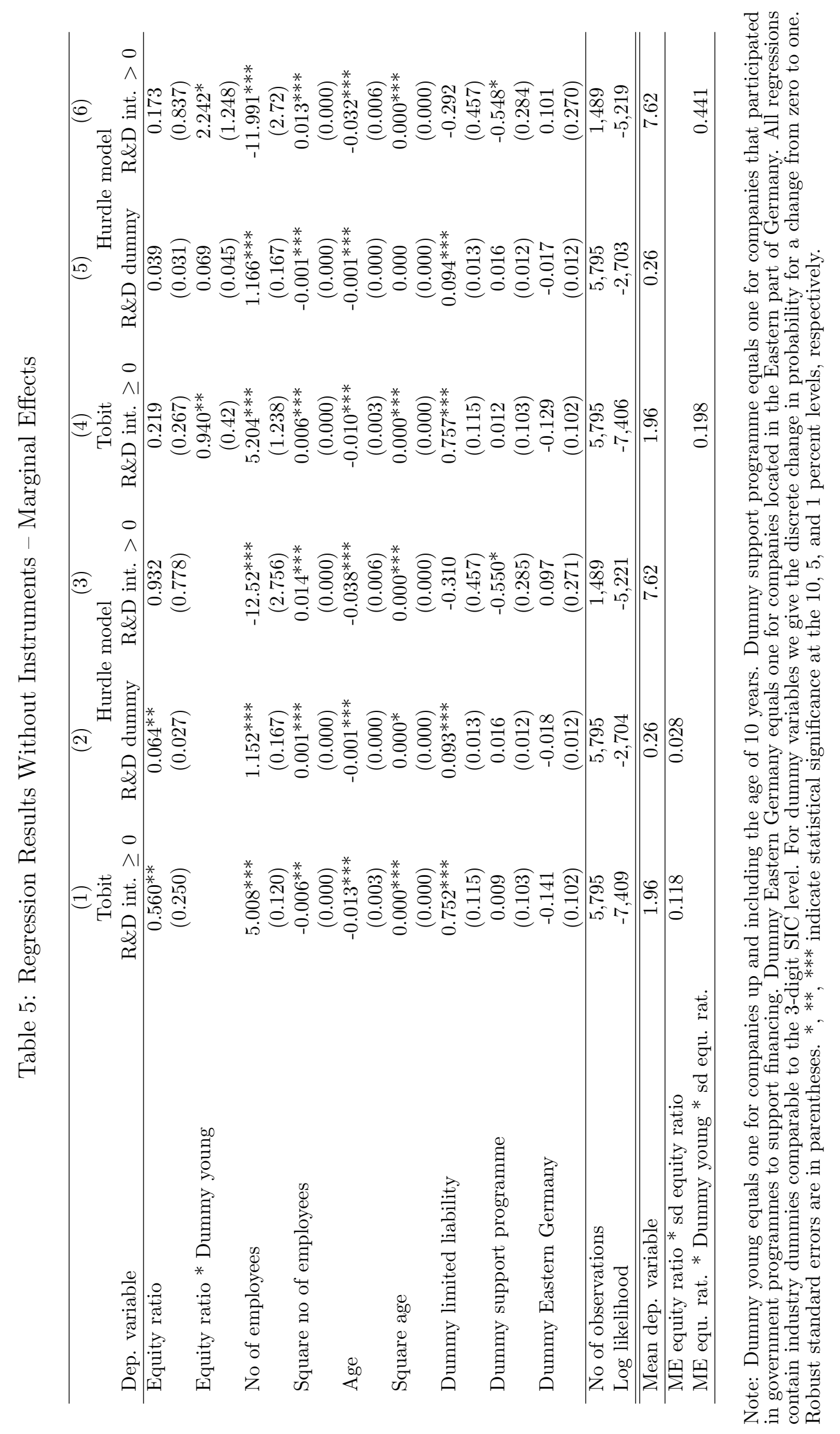


but not on the decision to undertake R\&D. This suggests that equity financing is only important for higher levels of R\&D intensity, such as e.g. young high-tech firms have. If R\&D is only a minor part in the overall activities of the company, young companies do not have a special requirement in terms of equity to finance their $R \& D$ activities. It can be that in these firms the level of overall risk is low enough for banks to be willing to extend loans. Another explanation could be that these companies can pledge enough collateral from other activities to satisfy the requirements of the bank for financing their low intensity R\&D activities. Besides the statistical significance, the effect is also economically important. In the Tobit model of column (3) a one standard deviation increase in the equity ratio increases the R\&D intensity by 0.25 percentage points or by more than 10 percent. When only $R \& D$ performing companies are considered, the R\&D intensity increases by 0.8 percentage points, an increase of also about 10 percent. In the instrumented regressions some of the additional control variables lose their significance, but the ones who remain significant always keep their sign.

Table 7 shows results with the instrument financial standing. The results are very similar to the ones obtained with the instrument local banking competition. The equity ratio has again a significant influence on the $\mathrm{R} \& \mathrm{D}$ intensity for young companies. The size of the effects is about the same for both instruments, which shows the robustness of the results. Compared to the regressions without instruments, the size of the effects are a bit larger. One explanation can be measurement error in the variables that biases the uninstrumented coefficients towards zero, another explanation can be a negative influence of reverse causality. However, it is theoretically not expected that R\&D intensity has a negative influence on the equity ratio.

The analysis suggests that specifically young companies have problems with the financing of $R \& D$ activities. The equity ratio exerts an important influence on the R\&D intensity of young but not of old companies. Whereas old companies have had time to build up equity via retained profits, young companies have to rely on the original investment of the owners. In addition, should additional financing be required while the R\&D project is executed, older companies can rely more on bank loans, as we saw in a previous section that older companies have a lower probability of not obtaining a loan offer. Young companies need to provide a financial cushion for bad times themselves.

Unfortunately, our analysis does not provide direct evidence that young companies are 


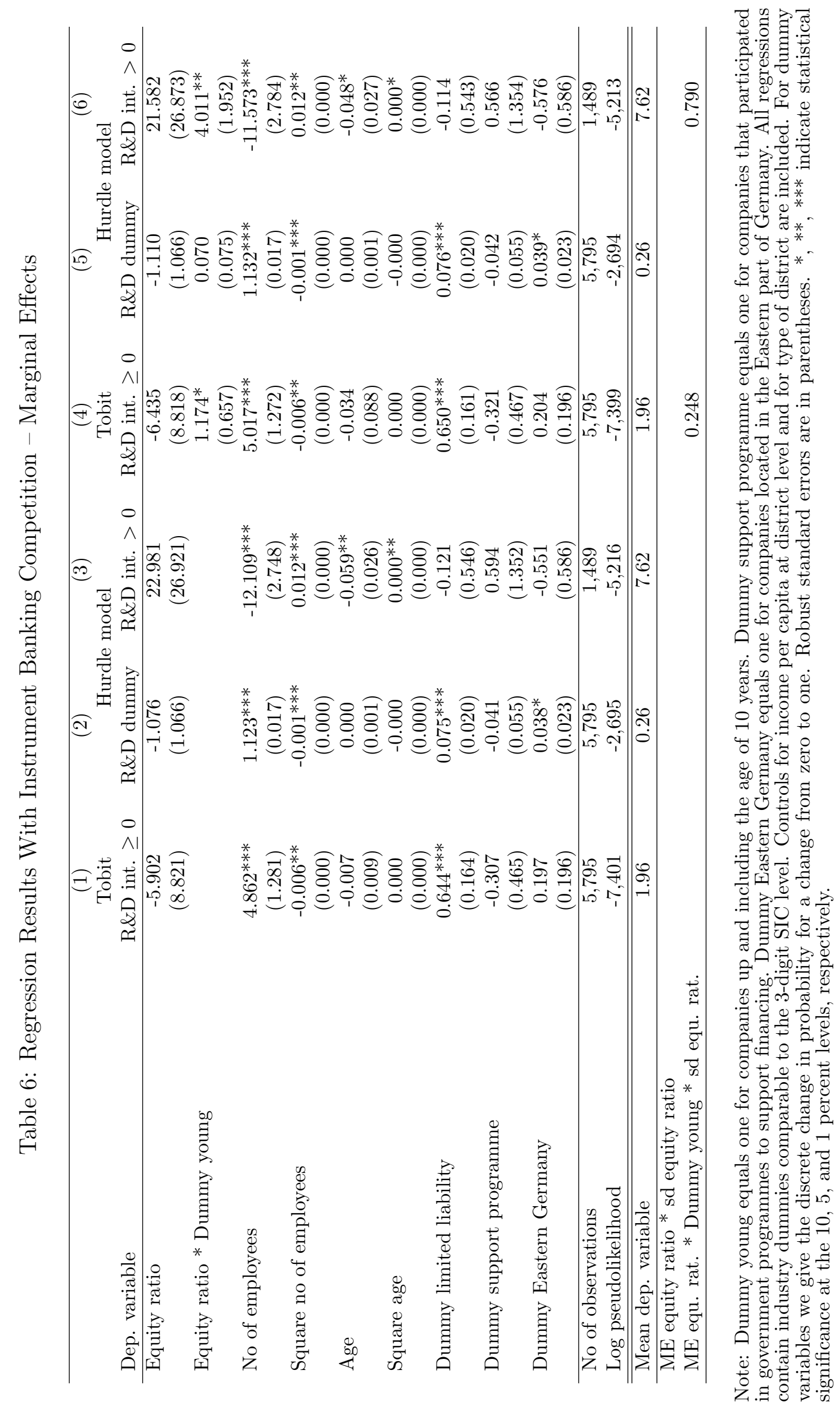




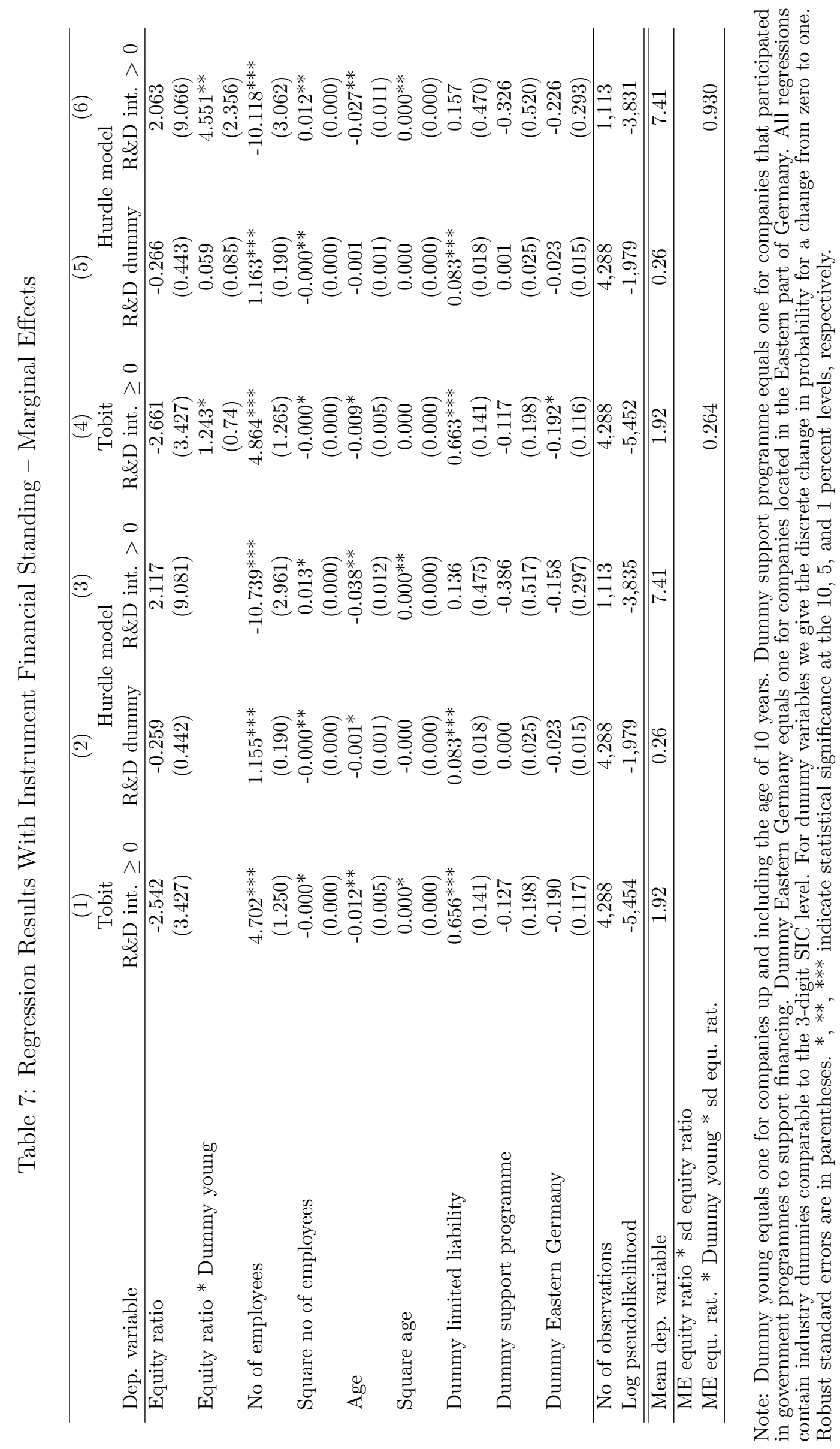


restricted by the availability of equity capital. If the original owners cannot increase their investment because of exhausted personal funds, it is, in principle, possible to admit additional owners to increase the equity capital available to the company. However, it is often not easy to find a person who is willing to invest his or her funds in a risky firm and who fits into the existing team of owners. In addition, many owners do not want to share control over the company. This last point is also often an argument against an investment of venture capitalists, since they demand influence as well. Even if owners are willing to share control, it is not easy to find a venture capitalist who is willing to engage in a young innovative company in Germany, because the VC market is not well developed. Hence, the owners of young companies may be only willing to engage in substantial R\&D, if enough equity is available or if the returns of the $R \& D$ project are high enough to make the acquisition of additional equity feasible and worthwhile.

In some situations the required returns for obtaining new equity from additional owners or venture capitalists may be too high. Companies may then refrain from undertaking R\&D. Since R\&D projects have positive externalities (Arrow (1962)), there may be a reason for the government to support R\&D activities of young companies, possibly through the improvement of the access to or the provision of cheaper equity capital.

\subsection{Robustness Checks}

Our main result of a significant influence of the equity ratio on the R\&D intensity of young companies is robust to a number of variations in the regression specification.

We obtain identical results if we use alternative measures of local banking competition as an instrument. We tried the Herfindahl index and the sum of the three largest market shares, each at the district level. The market share of a bank is measured as the number of subsidiaries a bank has in a district divided by the total number of subsidiaries in the district.

We also experiment with different cut-off points for the classification of a young company. There is a trade-off between including only very young companies and thereby reducing the number of observations and extending the range to older companies and possibly blurring the effects of young age. We obtain significant coefficients for the interaction term if we restrict the category of young companies to a maximum age of eight years, but the effect of 
equity ratio loses significance if we include companies up to the age of 12 . With the cut-off point of 10 years we found that the equity ratio is unimportant for old companies. This effect may dominate, if the definition of young is chosen too broadly.

Finally, we excluded companies from the analysis that reported an equity value of zero. The results also remain identical with this change.

\section{Conclusions}

Our analysis shows the importance of differentiating between young and old companies. In the regressions without instruments we find a positive relationship between the equity ratio and the R\&D intensity for young but not for old companies. This relationship can have two explanations: First, managers only choose to start R\&D projects if they have the necessary financial means in terms of equity capital to bring them to successful completion. Second, companies prefer to finance with equity since it is the relatively cheaper means in their situation or they are forced to finance with equity because they have no access to bank loans. Using local banking competition and the financial standing of the company as instrumental variables we find evidence for the first explanation.

The significance of the equity ratio only for young companies can mean that young companies are restricted in their R\&D activities by equity capital. Equity capital is no restriction for the $R \& D$ activities old companies, because they have had time to increase their equity endowment through retained earnings and can rely more on bank loans.

Interestingly, we only find a relationship of the equity ratio with $R \& D$ intensity but not with a dummy for $R \& D$ activity. This suggests that low levels of $R \& D$ activity do not require substantially higher levels of equity financing whereas young companies with high R\&D efforts, such as young high-tech firms, need equity financing. Such companies therefore depend on a functioning market for external equity. 


\section{References}

Acs, Z. J. and Audretsch, D. B. (1990), Innovation and Small Firms, MIT Press, Cambridge.

Aghion, P., Bond, S., Klemm, A. and Marinescu, I. (2004), 'Technology and Financial Structure: Are Innovative Firms Different?', Journal of the European Economic Association 2, 277-288.

Arrow, K. J. (1962), Economic Welfare and the Allocation of Resources for Invention, in R. Nelson, ed., 'The Rate and Direction of Inventive Activity', Princeton University Press, Princeton.

Berger, A. N. and Udell, G. F. (1995), 'Relationship Lending and Lines of Credit in Small Firm Finance', Journal of Business 68, 351-382.

Bester, H. (1985), 'Screening vs. Rationing in Credit Markets with Imperfect Information', American Economic Review 75, 850-855.

Bhagat, S. and Welch, I. (1995), 'Corporate Research \& Development Investments - International Comparisons', Journal of Accounting and Economics 19, 443-470.

Bond, S., Harhoff, D. and Van Reenen, J. (1999), 'Investment, R\&D, and Financial Constraints in Britain and Germany', Institute for Fiscal Studies Working Paper No. 99/5, London.

BVK (2005), 'BVK Statistik 2004', German Private Equity and Venture Capital Association (BVK), Berlin, www.bvk-ev.de.

Chiao, C. (2002), 'Relationship Between Debt, R\&D and Physical Investment, Evidence from US Firm-level Data', Applied Financial Economics 12, 105-121.

Cohen, W. M. and Levin, R. C. (1989), Empirical Studies of Innovation and Market Structure, in R. Schmalensee and R. D. Willig, eds, 'Handbook of Industrial Organization, Volume II', Elsevier Science Publishers, pp. 1059-1107.

Cragg, J. (1971), 'Some Statistical Models for Limited Dependent Variables with Applications to the Demand for Durable Goods', Econometrica 39, 829-944. 
Czarnitzki, D. (2005), 'Research and Development in Small and Medium-Sized Enterprises: the Role of Financial Constraints and Public Funding', Scottish Journal of Political Economy (forthcoming).

Elsas, R. and Krahnen, J. P. (2002), 'Collateral, Relationship Lending and Financial Distress: An Empirical Study on Financial Contracting', Goethe-Universität Frankfurt, Working Paper.

Fazzari, S. R., Hubbard, G. and Petersen, B. C. (1988), 'Financing Constraints and Corporate Investment', Brookings Papers on Economic Activity 1, 141-195.

Fritsch, M., Brixy, U. and Falck, O. (2004), 'The Effect of Industry, Region and Time on New Business Survival - A Multi-Dimensional Analysis', Freiberg Working Papers 04/2004.

Hall, B. H. (2002), 'The Financing of Research and Development', Oxford Review of Economic Policy 18, 35-51.

Harhoff, D. (1998), 'Are There Financing Constraints for R\&D and Investment in German Manufacturing Firms?', Annales d'Economie et de Statistique 49/50, 421-456.

Himmelberg, C. P. and Petersen, B. C. (1994), 'R\&D and Internal Finance: A Panel Study of Small Firms in High-Tech Industries', Review of Economics and Statistics 76, 38-51.

Hyytinen, A. and Pajarinen, M. (2005), 'Financing of Technology-Intensive Small Businesses: Some Evidence on the Uniqueness of the ICT Sector', Information Economics and Policy 17, $115-132$.

Krahnen, J. P. and Schmidt, R. H. (2004), The German Financial System, Oxford University Press, Oxford.

Lehmann, E., Neuberger, D. and Räthke, S. (2004), 'Lending to Small and Medium-Sized Firms: Is There an East-West Gap in Germany?', Small Business Economics 23, 23-39.

Link, A. N. and Bozeman, B. (1991), 'Innovative Behavior in Small-Sized Firms', Small Business Economics 3, 179-184.

Peters, B. (2004), 'Employment Effects of Different Innovation Activities: Microeconometric Evidence', ZEW Discussion Paper No. 04-73, Mannheim. 
Petersen, M. A. and Rajan, R. G. (1995), 'The Effect of Credit Market Competition on Lending Relationships', Quarterly Journal of Economics 110, 407-43.

Petersen, M. and Rajan, R. (1994), 'The Benefits of Firm-Creditor Relationships: Evidence From Small Business Data', Journal of Finance 49, 3-37.

Rammer, C., Zimmermann, V., Müller, E., Heger, D., Aschhoff, B. and Reize, F. (2006), Innovationspotenziale von kleinen und mittleren Unternehmen, ZEW Wirtschaftsanalysen, Bd. 79, Baden-Baden.

Schäfer, D., Werwatz, A. and Zimmermann, V. (2004), 'The Determinants of Debt and (Private) Equity Financing: the Case of Young, Innovative SMEs from Germany', Industry and Innovation 11, 255-248.

Scherer, F. (1991), Changing Perspectives on the Firm Size Problem, in Z. J. Acs and D. B. Audretsch, eds, 'Innovation and Technological Change: An International Comparison', University of Michigan Press, Ann Arbor, pp. 24-38.

Singh, M. and Faircloth, S. (2005), 'The Impact of Corporate Debt on Long Term Investment and Firm Performance', Applied Economics 37, 875-883.

Stifterverband (2005), 'FuE Info 1/2005', Stifterverband für die Deutsche Wissenschaft, Essen.

Stiglitz, J. (1985), 'Credit Markets and the Control of Capital', Journal of Money, Credit and Banking 17, 133-152.

Stiglitz, J. E. and Weiss, A. (1981), 'Credit Rationing in Markets with Imperfect Information', American Economic Review 71, 393-410.

Williamson, O. E. (1988), 'Corporate Finance and Corporate Governance', Journal of Finance 43(3), 567-591.

Wooldridge, J. M. (2002), Econometric Analysis of Cross Section and Panel Data, MIT Press, Cambridge, Massachusetts.

Zimmermann, V. and Karle, H. (2005), 'Das Geschäftsklima im deutschen Beteiligungskapitalmarkt. Entwicklung und Einflussfaktoren', Finanz Betrieb 6/2005, 445-455. 